\title{
HISTORY
}

\section{ФОРМИРОВАНИЕ И РАЗВИТИЕ КРАЕВЕДЕНИЯ КАРАКАЛПАКСТАНА (1920-1930-е ГГ.)}

\author{
3. Кыдырниязов \\ Младший научный сотрудник, \\ Республика Каракалпакстан, г. Нукус, \\ Каракалпакский научно-исследовательский институт гуманитарных наук, \\ Каракалпакского отделения Академии наук Республики Узбекистан
}

DOI: https://doi.org/10.31435/rsglobal_ijitss/31102019/6755

\section{ARTICLE INFO}

Received 21 August 2019

Accepted 14 October 2019

Published 31 October 2019

\section{KEYWORDS}

History, local history, Karakalpakstan, ethnography, expedition, research institute, folklore. \begin{abstract}
The history of the formation and development of the local history movement in Karakalpakstan is a poorly studied topic in native historiography. Thus, it has recently been of increasing interest from our scientists. A significant increase of researchers' interest to the problem of regional studies is currently reflected in the need of the making comprehensive works on the history of particular cities and regions of Karakalpakstan. In modern conditions, when the revival of the local history movement, begun in the 1920 s, continues, the success of this initiative is not possible without resorting to the history of the formation and development of native local history.
\end{abstract}

Citation: Z. Kydyrniyazov. (2019) Formation and Development of the Local Studies of Karakalpakstan (1920-1930s). International Journal of Innovative Technologies in Social Science. 7(19). doi: 10.31435/rsglobal_ijitss/31102019/6755

Copyright: (C) 2019 Z. Kydyrniyazov. This is an open-access article distributed under the terms of the Creative Commons Attribution License (CC BY). The use, distribution or reproduction in other forums is permitted, provided the original author(s) or licensor are credited and that the original publication in this journal is cited, in accordance with accepted academic practice. No use, distribution or reproduction is permitted which does not comply with these terms.

Актуализация проблемы краеведения во многом определяется современной ситуацией в исторической науке, в которой наблюдается тенденция к развитию регионалистики, изучению эволюции и формирования научной деятельности в периферии. Изучение локальной истории является важным элементом исторической науки в целом. Сложный комплекс элементов, что включает в себя понятие «краеведения», оно и история, и этнология, археология, геология, ботаника края, и прочие направления краеведческой деятельности, предопределяет увеличение интереса к этой проблеме, как историков, так и ученых других дисциплин. История формирования и развития краеведческого движения в Каракалпакстане в последнее время вызывает все большего интереса со стороны ученых. Значительное увеличение интереса исследователей к проблеме краеведения в настоящее время отразилось в необходимости создания комплексных трудов по истории отдельных городов и районов Каракалпакстана.

С установлением на территории Каракалпакстана нового строя в середине 1920-х годов, стали проводиться мероприятия по переустройству хозяйства, быта и культуры народа, всего уклада жизни, что требовало серьезного и всестороннего изучения расселения и численности народа, особенностей его социального строя. В конце 1920-х годов руководство Каракалпакстана направило официальное письмо в адрес Академии наук СССР с предложением о проведении научных экспедиций по изучению недр Султануиздага, Устюрта и других районов. В этот период происходит формирование краеведения, как основа научных учреждений, организуются экспедиции, развертывается широкая подготовка научных кадров. 
Несмотря на бурную деятельность, этот период исследований носила в основном собирательный характер. Полученные материалы не подвергались научному анализу, и большинство трудов остались неопубликованными.

Основными проблемными темами по изучению истории Каракалпакстана в 1920-1930 гг. являлись: национально-этнический и племенной состав населения, определение расселения народов, составление этнографической карты, и т.д. В 1928-1929 гг. в изучении этнографии каракалпаков приняли участие наряду с профессорско-преподавательским составом и студенты Туркестанского государственного университета. Особенно интересные сведения собрала А.С.Морозова, которая написала работу «Материалы для изучения языка и быта каракалпаков».

В сентябре месяце 1928 года под руководством А.Л.Мелкова была организована «Каракалпакская этнографическая экспедиция». Для осуществления работ по собранию экспонатов был выделен аванс в сумме 3747 рублей. Члены экспедиции должны были изучать памятники истории и собирать экспонаты. А также, в планы экспедиции входило обследование кустарных промыслов. Кроме кустарных промыслов Мелковым сделаны фотографии, охватывающие практически все сферы хозяйства каракалпаков того времени ${ }^{1}$. Работа экспедиции была поддержана интеллигенцией нашего края. Во главе с Карабаевым и Ербаевым представители местной интеллигенции отправляют в ОблОНО письмо, где просят организовать на основе собранных данной экспедицией материалов музейную выставку. И 16 мая 1929 года в городском клубе Турткуля краеведами была организована выставка ${ }^{2}$. В ней были представлены национальные одежды каракалпаков, старинные рукописи, хозяйственная утварь, книги, снимки исторических памятников, картины. В организации этой выставки активное участие приняли работавшие в составе «Каракалпакской этнографической экспедиции» московские студенты А.Н.Баскаков. А.Давлетов, Н.В.Торчинская и первые местные краеведы К.Аимбетов, этнограф из Ташкента А.Морозова.

В том же 1929 г. Н.Баскаковым был снят этнографический фильм «Каракалпакстан», который обсуждался на общественном просмотре. Этот фильм был продемонстрирован в 1930 г. на Всеказахском Краеведческом съезде в г. Алма-Ате. В фильме была показана традиционная культура населения Чимбайского и Ходжейлийского районов. Значительную часть собранных и зафиксированных материалов Н.Баскаковым и А.Давлетом составили фольклорные тексты, сведения о родоплеменных отношениях, семейном быте, материальной культуре населения Каракалпакстана.

15 июля 1930 г. на первом научно-исследовательском краеведческом съезде в г. АлмаАта Н.А.Баскаков сделал информационное сообщение об отсутствии краеведческого общества в Каракалпакстане и об огромном значении работы такого общества на местах. Доклад был принят к сведению, и дальнейшая работа была поручена Дворникову и Баскакову³.

В 1930 г. в июле-сентябре Центральным Комитетом нового алфавита (далее - ЦКНА) в наш регион был командирован С.Е.Малов. Данная экспедиция, главным образом, носила лингвистический характер и ставила целью изучение и выявление особенностей каракалпакского языка. Несомненной заслугой участников экспедиции стало изучение наречий, которое оставалось до тех пор вне поля зрения интересов тюркологов

Экспедиционные работы проводились на территории Караузякского и Чимбайского районов. В ней приняли участие сотрудники института К.Аимбетов, О.Кожуров и У.Кусекеев. Материалы, собранные ими, составили рукопись под названием «Основные этапы истории каракалпаков», которая освещает некоторые вопросы происхождения каракалпаков на основе письменных источников ${ }^{4}$.

Придавая особую важность организации научно-исследовательского института, правительство автономной республики приняло меры по широкой организации научноисследовательской работы в Каракалпакстане. В результате этих мер в 1931 г. был организован Каракалпакский комплексный научно-исследовательский институт ${ }^{5}$. Институт был укомплектован как приезжими учеными, так и представителями местной национальности К.Аимбетов, Ж.Урумбаев, Т.Бекимбетов, начали работать в институте после 1933 г.

\footnotetext{
${ }^{1}$ ЦГА РК, ф.12, оп.3, д.160, л.459.

2 ЦГА РК, Ф.12, Оп.3, Д.160, Л.459.

${ }^{3}$ ЦГА РК, Ф.26, оп.1, д.351, л.5

${ }^{4}$ ЦГА РК, Ф.26, оп.1, д.351, л.18.

${ }^{5}$ Камалов С. Штабу советской науки - 250 лет. Вестник ККФАН УзССР. 1974 г.№5, с.48.
} 
Комплексный научно-исследовательский Институт ККАССР находился в Турткуле. Основные задачи и проблемы, определяющие работу учреждения: изучение естественных богатств, производительных сил, экономику ККАССР, ее культуру, быт населения, а также историю. Конкретные дисциплины - история, этнография, языковое, строительство, сельское хозяйство, этнология, геоботаника, педагогика, гидрофенометереология, энергетика.

В 1932 г. были отмечены заслуги за активное участие в деле организации научноисследовательской работы и культурного развития ККАССР:

1. Н.А.Баскаков, первый активный помощник по организации комплексного научноисследовательского института. Он был первый среди ученых СССР, который уделил особое внимание научному изучению каракалпакского языка. Баскаков дал описание каракалпакского языка, которое было изложено им в его научном труде «Грамматика каракалпакского языка» (Издание ККНИИ 1932 г.). По словам известного тюрколога проф. Малова, данная работа Баскакова, «является большим достижением тюркологической науки» ${ }^{1}$.

2. Ибадуллаев Кенжебай, как научный сотрудник ККНИИ уделивший огромное внимание разработке орфографии каракалпакского языка. Разработан им проект орфографии.

3. П.А.Воронцовский старший научный сотрудник с 25-летним стажем. Работал в Каракалпакском институте с момента его организации. За годы работы в издании ККНИИ вышли его труды о ККАССР: «Экологические условия обитания саранчи в нижней дельте Амударьи»; «Материалы к изучению этномофауны ККАССР.

4. Н.Н.Бобровский бывший заведующим лабораторной станцией Чимбая и в дальнейшее время зав. Гидрометереологической станции Гидрометкомитета ККАССР, принимал активное участие в деле восстановления и расширения гидрометсети за 8 месяцев. Ими были установлены и вступили в строй 2 важные станции, имеющие союзное и международное значение (Тамды и Муйнак). По его инициативе Государственный Метереологический Комитет СССР принял решение об организации Гидрологической станции на острове Возрождения, которая была открыта в 1933 г.

Институт имел химико-технологическую лабораторию в г. Турткуле, основанный в 1932 г., энтомологический кабинет, почвенный кабинет, пустынно-песчаный кабинет, исторический кабинет, лингвистический и этнографический кабинет ${ }^{2}$.

В ККНИИ имелась научная библиотека, в фондах которой было 1438 переплетных единиц книг, площадь помещений составлял 12 кв.м. ${ }^{3}$ В 1932 г. Каракалпакский комплексный институт проводил работу научно-исследовательского характера по ниже следующим темам:

1) Борьба с потерями в сельском хозяйстве. Народно-хозяйственное значение вредителей и полезных насекомых ККАССР и их видовой состав, условия обитания саранчи в дельте Амударьи.

2) Проблема каракалпакского языка и письменности. Орфография каракалпакского языка и грамматика каракалпакского языка. Библиография ККАССР.

3) Проблема освоения земель древнего орошения, оценочно-почвенные работы в районах, совхозах.

4) Фольклор каракалпаков, и т.д.

В год образования Каракалпакского комплексного научно-исследовательского института по инициативе академика А.Е.Ферсмана в Каракалпакстан была направлена экспедиция под руководством А.Ф.Соседко с целью геохимического изучения ${ }^{4}$.

Через год было решено направить в Кызылкумы комплексной экспедиции для всестороннего обследования природных богатств этого региона. Следует отметить, что ранее разрозненные отдельные тематические исследования были объединены в крупные комплексные экспедиции. Такой метод организации экспедиций позволял изучить весь комплекс производительных сил данного региона.

С целью обобщения собранных экспедициями материалов и принятия по ним ряда практических мер по инициативе правительства Каракалпакстана и Академии наук СССР была

\footnotetext{
${ }^{1}$ Отзыв проф. Малова в газете «Советская Каракалпакия». ЦГА РК Ф.229, оп.1, д.16, л.14.

2 ЦГА РК Ф.156, оп.2, д.139, л.21.

${ }^{3}$ ЦГА РК Ф. 156, оп.2, д.139, л.23.

${ }^{4}$ ЦГА РК, Ф.26, Оп.1, Д.351, Л.18.
} 
созвана 18-25 марта 1933 г. в г. Ленинград (ныне г. Санкт-Петербург) Первая конференция по изучению производительных сил Каракалпакстана. В ней приняли участие, как руководители Каракалпакстана, так и видные ученые, которые выступали со своими докладами ${ }^{1}$.

В частности, среди них были: К.Нурмухамедов, который руководил делегацией; Д.М.Логинов - заместитель руководителя делегации, он выступил с докладом «ККАССР во второй пятилетке»; А.Кантарбаев - Наркомздрав ККАССР, с докладом «Состояние и перспективы народного здравоохранения в ККАССР: местные болезни и борьба с ними»; А.Гнеденко - КНИИ, с докладом «План исследовательских работ на 1933 г.»; Г.М.Давыдовский - КНИИ, с докладом «Земли древнего орошения и перспективы их освоения»; Н.А.Воронцовский - КНИИ, с докладом «Энтомофауна ККАССР и ее роль в сельском хозяйстве»; В.И.Вертегов - Наркомпрос ККАССР, с докладом «Культурная революция в ККАССР»; Г.Убайдуллаев - Наркомпрос ККАССР, с докладом «Орфография каракалпакского языка»; Комков - Госземтрест, с докладом «Состояние картографической изученности ККАССР»; Петров - Комитет оседания, с докладом «Проблемы оседания кочевников»; Д.В.Альбанов - Госплан, с докладом «Транспорт и перспективы его развития»; Соколов - Госплан, с докладом «Легкая кустарная промышленность ККАССР и перспективы ее развития»; К.Джандеркин - Госплан, с докладом «Социальная реконструкция животноводства»; Семенов - Водхоз, который выступил с двумя докладами «Перспективы ирригации ККАССР»; «Дейгиш и меры борьбы с ним»; Джувалиев - Лесхоз трест, с докладом «Экологическое состояние лесов ККАССР».

Значение данной конференции было освещено в публикациях С.К.Камалова, В.В. Германовой и т.д., которые рассматривают все эти процессы с формированием краеведения Каракалпакстана. На заседании СНК ККАССР от 29 июня 1933 года был подведен итог конференции. Решением СНК ККАССР от 27 июля того же года были переведены в Москву для издания трудов конференции две тонны бумаги и 20 тыс. руб. В 1934г. в Ленинграде были опубликованы в двух томах труды этой конференции ${ }^{2}$.

Функционирование Каракалпакского комплексного научно-исследовательского института играло важную роль в реализации вышеуказанных краеведческих экспедиций.

К сожалению, существование комплексного института было непродолжительным. В марте 1936 г. по решению СНК комплексный институт был разделен на несколько секторов, что означало его расформирование. В постановлении областного комитета ВКП(б) и СНК ККАССР говорилось о том, что было принято решении организации двух республиканских зональных станций (хлопководческий и животноводческий), и также из-за отсутствия научных кадров расформировать научно-исследовательский институт.

Для развития народного хозяйства и культуры республики существовала нужда в высококвалифицированных кадрах. Поэтому многие представители Каракалпакстана были направлены на учебу в Москву, Ленинград, Ташкент, Алма-Ату и другие города.

В современных условиях, когда продолжается начатое в 20-х годах прошлого столетия возрождение массового краеведческого движения, успешность этого начинания не возможна без обращения к опыту и традициям отечественного краеведения. Само по себе понятие «краеведческое движение» включает множество элементов и основывается на организованной, массовой общественной деятельности, выразившейся в форме разнообразных добровольных и государственных объединений и союзов граждан, направленной на всестороннее изучение отдельных регионов и местностей.

\footnotetext{
${ }^{1}$ ЦГА РК, Ф.322, Оп.1, Д.9, Л.105.

${ }^{2}$ Камалов С., Германова В. Москва - Каракалпакстан. Нукус,1986; Камалов С., Германова В. Советская Россия и Каракалпакия: интернациональное сотрудничество и братская взаимопомощь. // Общественные науки Узбекистане (ОНУ), 1983, №1; Камалов С., Германова В. У истоков изучения культурного наследия Каракалпакского народа. // ОНУ, 1994, №1-2.
} 